\title{
Personal resources and turnover intention among private- sector employees: Does work engagement still matter?
}

\author{
Ratna Tri Hardaningtyas ${ }^{1 *}$ \\ ${ }^{1}$ Department of Management, Faculty of Economics and Business, Universitas Islam \\ Malang, Malang, Indonesia \\ *Corresponding Author(s) Email: ratnatyas@unisma.ac.id
}

\section{ABSTRACT}

Work engagement has emerged as a core element of talent management to acquire and retain high-performing employees in the labor market and a potential bright spot for business success. Due to the aforementioned positive influences and benefits of improving employees' work engagement, many organizations put more effort towards enhancing and maintaining levels of work engagement as their top priority for an effective human resource system. This study aimed to investigate the mediating effects of employees' work engagement in the relationships between their personal resources (self-efficacy, organizationalbased self-esteem, and optimism) and turnover intention. A total of 119 survey responses collected by convenience sampling and analyzed by using structural equation modeling (SEM). This study concluded that there is a positive relationship between self-efficacy, organizationalbased self-esteem, optimism, and work engagement. The mediation role of work engagement in the relationship between self-efficacy, organizational-based self-esteem, optimism, and turnover intention proves significantly in this study. Interestingly, this study found that there is a positive relationship of self-efficacy on turnover intention which means that the higher level of self-efficacy does not indicate the lower turnover intention. Employees with a high level of self-efficacy believe that they are giving too much to their organization Therefore, they eventually negotiated more for higher salaries while at the same time seeing more alternative jobs/organizations offers in case they are not appreciated enough for what they do for organizations.

Keywords: Work Engagement; Self-Efficacy;

Organizational-Based Self-Esteem; Optimism;

Turnover Intention
JEL Code:

J28, J29

DOI:

10.31106/jema.v17i1.4989

Article History:

Received 2019-12-16

Reviewed 2019-12-25

Revised 2020-01-12

Accepted 2020-01-28

Licensed:

CC-BY 


\section{Introduction}

According to Saks (2006) and Wollard \& Shuck (2011), to bring about better change among employees in a company, work engagement has been heralded as an important factor because it has become a new concept that is constantly developing. This common regard starts with the idea that employees will have a higher enthusiasm for their work when they are in a positive mindset. Therefore, individual and organizational productivity in the company will increase. Researchers have pointed out that work engagement gives rise to various positive results in the organization, such as better work quality, innovation, and commitment to the organization among employees and higher profits for the company (Bakker \& Bal, 2010; Hakanen et al., 2006; Xanthopoulou et al., 2009; Zhang \& Bartol, 2010). Other researchers add that work engagement also impedes employees' absence, workrelated stress, and turnover intention (Saks, 2006; Schaufeli \& Bakker, 2004; Schaufeli et al., 2009; Wefald et al., 2011).

In addition to such attempts in HRD approaches, Bakker \& Demerouti (2008) presented, as the research framework, the job require-resources (JD-R) model of work engagement. They maintained that either separately or simultaneously, job and personal resources influence work engagement positively, resulting in better success in terms of work quality, innovation, and turnover intention. According to Bakker et al. (2014), the incorporation of work engagement is typically classified by psychologists into two perspectives which are job resources as a situational variable and personal resources as an individual variable. Xanthopoulou et al. (2007) revealed that based on the JD-R work-engagement model, job resources include the physical, social and organizational components of work in pursuing work objectives and promoting personal growth. Whereas personal resources are elements of self-assessment or positive self-assessment which traditionally relates to endurance and indicates certain employees' concept of their ability to manage and affect their workplace positively (Bakker \& Demerouti, 2008; Hobfoll et al., 2003; Xanthopoulou et al., 2007). According to Xanthopoulou et al. (2007), although job and personal resources are both important indicators of work engagement, most surveys tend to concentrate on the correlation between job resources and work engagement. Xanthopoulou et al. (2007) stated in this aspect that individuals with personal resources are assured in their strengths and capabilities, and are hopeful of their prospects. Therefore, they will explore or identify other dimensions of their surroundings that lead to the confrontation of objectives and, hence, to the advancement of work engagement. This is required to explain how resources relate to work engagement and 
to show detailed consequences for HR experts. Further scientific research is needed to address the personal resources' effects on work engagement and effective organizational outputs.

Additionally, for a company to be able to keep successful talent management, turnover intention as a part of work engagement is a critical concern in connection with maintaining human capital (Carmeli \& Weisberg, 2006; Hughes \& Rog, 2008). Carmeli \& Weisberg (2006) defined turnover intention as an individual's intention to voluntarily quit his or her position in a company soon. According to Mobley et al. (1979), the direct cause of turnover action is perceived as turnover intention. In this way, an individual's turnover intention is a strong indicator of his or her subsequent actions (Carmeli \& Weisberg, 2006; Shuck et al., 2011) and the best possible predictor of the real turnover (Egan et al., 2004). While Saks (2006) and Schaufeli \& Bakker (2004) have explored employment resource relationships as a situational aspect, work engagement, and turnover intention, only a few studies have been done to examine the significant relationships among those elements given the significance of personal factors in deciding to resign. Besides, from the viewpoint of HR experts in the Indonesian private industry, which is marked by limited job protection and high job instability, the personal resources and degree of work engagement of every worker can be important turnover indicators.

A lot of current work has indicated how recent studies undervalue the effect of individual variance on work agreement. Undoubtedly, formerly undisclosed characteristics of personal resources may shed considerable light on employees' differences in work engagement. From this viewpoint, this research examines personal resources that are common among employees such as self-efficacy, organizational based self-esteem (OBSE), and optimism that is critical to job-related psychological health (Hobfoll, 2002; Xanthopoulou et al., 2007, 2009).

\section{Literature Review}

To incorporate the direct causal link between personal resources, work engagement, and turnover intention, this study adopted the conservation of resources (COR) theory of Hobfoll's (1989) - which was also used in other research on work engagement such as Halbesleben (2010) and Weigl et al. (2010) - as its theoretical framework. According to COR theory, workers should employ their creative energy through the creation and retention of resources; that way they can preserve their engagement. Notably, the world economy has undergone a slowdown of growth following the 2008 economic crisis. Because of intense job performance demands and the danger of being terminated by employers, workers have 
continually alienated from their jobs; in the end, this condition may lead to unwanted individual and organizational effects.

COR theory has gained further recognition in such stressful working environments as a buffering tool for obtaining, retaining and sustaining employee resources to cope with stress and improve psychological health. COR theory maintains that employees are spending their resources to offset potential resource shortages; thus, they are constantly seeking to maintain an acceptable amount of resources to avoid the loss of current resources. If not, profound psychological effects arise when the resources expended do not surpass the advantages predicted. The presence of weak resources encourages workers to get spiral which enhances patterns that facilitate constructive mutual relationships between different kinds of work demands. Alternatively, according to Salanova et al. (2010), it is more likely that individuals who fall short of such resources will be vulnerable to more energy loss and less resource development.

A constructive mutual relationship may occur in which work engagement and personal resources depend on each other. Furthermore, by using their self-efficacy, OBSE, and optimism, individuals with personal resources are more able to invest in their work overtime. Motivated workers tend to be more empowered by optimizing the beneficial effect of their current resources and more quickly creating a gain spiral for new resources to be added. In comparison, when personal resources disappear or when expended resources don't meet the anticipated amount of performance, employees are frequently alienated in their work. Nevertheless, as Hobfoll (2002) concluded, the impact of a gain spiral seems to provide a moderate effect on the degree of engagement, whereas a loss spiral tends to worsen the process of resource loss more strongly and faster. It is important to analyze how personal resources such as self-efficacy, organizational self-esteem, and optimism help alleviate negative effects of job demands by generating immediate relief and maintaining work energy to reduce overall the risk of talent loss triggered by turnover intention. Hence, based on a robust theoretical basis, our research hypothesizes that this segment provides a thorough analysis of the current literature on each research variable and the important relationships between them.

\section{Work Engagement}

Schaufeli et al. (2002) defined work engagement as "a positive, fulfilling, work-related state of mind that is characterized by vigor, dedication, and absorption." Vigor means an eagerness and commitment to participate with high energy levels in one's career, along with 
endurance and patience in overcoming challenges while at work. Dedication is marked by seeking true intent in one's profession and feeling a sense of value, love, inspiration, respect, and motivation. Absorption means full concentration and involvement in one's career as if time is moving quickly and it is hard to be unemployed (Schaufeli \& Bakker, 2010). Committed individuals are typically considered to be feeling positive emotions. Therefore, committed workers are typically enthusiastic, self-assured, and positive; these constructive work strategies are directly related to good work quality - the abundance of accomplishments increases employability. This mutual enhancing interaction is more likely to engage workers deeply in their roles and can minimize or erase work exhaustion (Kim et al., 2013; Saks, 2006). Also, dedicated workers who express their confidence and enthusiasm and demonstrate constructive attitudes to their colleagues cultivate a favorable organizational environment that has a direct effect on lower turnover intentions (Demerouti \& Cropanzano, 2010).

\section{Self-Efficacy, Organizational-Based Self-Esteem, and Optimism of Personal Resources}

According to Milam et al. (2019), self-efficacy refers to the understanding or beliefs of individuals about their ability to execute and finish their overall task. Furthermore, Picton et al. (2018) and Pradesa et al. (2019) stated that the more confidence the workers have in their abilities to do a task, the more dedicated and emotionally invested they become to their jobs and company. Meanwhile, Lin et al. (2018) described organization-based self-esteem (OBSE) as the level to which individuals believe in their importance, competencies, capacity, and significant position as part of an organization. Individuals with higher organization-based self-esteem usually find themselves important to their organizations, making them more dedicated to their work and have more desire to carry out their work well within the company (Mauno et al., 2007). Scheier et al. (2001) defined optimism as the inclination to assume that one will achieve positive results in life in general. Optimists are more likely to assign positive outcomes to the self than pessimists while trying to link negative outcomes to external causes. These three personal resource elements make workers eagerly involved, remain embedded in their work, and function with higher energy levels. This positive dynamic has been confirmed by empirical literature (Choi \& Kang, 2012; Luthans \& Peterson, 2002; Mauno et al., 2007; Xanthopoulou et al., 2007, 2009). The above arguments offer the following theories. The discussions above suggest the following hypotheses.

$\mathrm{H}_{1 \mathrm{a}}$ : Self-efficacy has a positive effect on work engagement.

$\mathrm{H}_{1 \mathrm{~b}}$ : Organizational-based self-esteem (OBSE) has a positive effect on work engagement. 
$\mathrm{H}_{1 \mathrm{c}}$ : Optimism has a positive effect on work engagement.

Furthermore, personal resources such as self-efficacy, OBSE, and optimism could minimize turnover intention. Strong negative associations between a personal resource variable and turnover intention have been revealed by past empirical evidence (Bowling et al., 2010). Luthans et al. (2006) established a negative correlation between self-efficacy and turnover intention. Bowling et al. (2010) added that meta-analytic research published in the organizational-based-self-esteem literature also found that OBSE has a negative association with turnover intention. Similarly, Tuten \& Neidermeyer (2004) presented evidence to indicate that optimism is correlated weakly with turnover intention. With this scientific proof, this research suggests that the perception of working conditions by workers is affected by personal resources. According to Bowling et al. (2010), employees with a higher level of personal resources will consider any work situation as a chance to try to reform their workplace. This research thus indicates that a higher degree of self-efficacy, organizationalbased self-esteem, and optimism means less chance of turnover intention. Therefore, this study suggests that a higher level of self-efficacy, organizational-based self-esteem, and optimism is related to a lower level of turnover intention.

$\mathrm{H}_{2 \mathrm{a}}$ : Self-efficacy has a negative effect on turnover intention.

$\mathrm{H}_{2 \mathrm{~b}}$ : Organizational-based self-esteem (OBSE) has a negative effect on turnover intention.

$\mathrm{H}_{2 \mathrm{c}}$ : Optimism has a negative effect on turnover intention.

\section{Turnover Intention}

The high rate of turnover intention among employees is widely understood as a damaging characteristic to be prevented in the work environment. Morrell et al. (2001) and Schyns et al. (2007) stated that despite a lot of literature on turnover, there is no widely recognized explanation of why workers want to leave corporations. However, Schyns et al., (2007) and Winterton (2004) maintained that it is closely linked to low work fulfillment, productivity and recruitment, and retention costs, along with the potential loss or lack of specific/implicit expertise and competencies of existing workers due to the real high turnover. According to the meta-analysis report by Halbesleben (2010), there is a clear negative correlation between work engagement and turnover intention. In the Asian frameworks, a few observational studies (Agarwal et al., 2012; Bhatnagar, 2012; Kim, 2017) have found a substantially negative impact of work engagement on turnover intention. Committed staff is, therefore, according to Halbesleben \& Wheeler (2008), less likely to leave their positions because they are more closely identified with their work and can appreciate and secure their 
roles and personal resources in their working environment. As such, previous literature suggested that those employees with high work engagement are more likely to have less turnover intention, which suggests the following hypothesis.

$\mathrm{H}_{3}$ : Work engagement negatively influences their turnover intention.

Individuals with a higher degree of self-efficacy, organizational-based self-esteem, and optimism can gain a greater level of work engagement that contributes to less turnover intention in their organizations. Personal resources like self-efficacy, organizational-based self-esteem, and optimism have a minimal impact as a form of individual factors on turnover intention. They can serve as psychological pillars that enhance work engagement, which in turn contribute to accrued capital in a supportive workplace. This approach can be an effective opportunity to remain with the current company and workers may be unwilling to give up the advantages of preserved resources that are entirely worthless outside their company. For that reason, it is more apparent that work engagement mediates the negative correlation between personal resources such as self-efficacy, organizational-based selfesteem, and optimism and turnover intention. All things considered, work engagement can be believed to mediate the relationships between self-efficacy, organizational self-esteem, motivation, and turnover intention; this is partially confirmed by empirical research by Kim et al. (2013) and Shahpouri et al. (2016). The discussions above suggest the following hypotheses:

$\mathrm{H}_{4 \mathrm{a}}$ : Self-efficacy that is mediated by work engagement affects employees' turnover intention.

$\mathrm{H}_{4 \mathrm{~b}}$ : Organizational-based self-esteem (OBSE) that is mediated by work engagement affects employees' turnover intention.

$\mathrm{H}_{4 \mathrm{c}}$ : Optimism that is mediated by work engagement affects employees' turnover intention.

\section{Methods}

Due to the reason of limited accessibility to employees in organizations, this study used a convenience sampling as a sampling technique approach. Through the sampling process, 171 responses were collected. After removing 52 incomplete responses, a total of 119 cases were used in this study. Structural equation modeling (SEM) with descriptive statistics and a common method bias test used as data analysis. To evaluate the overall model fit of the structural model, this study employed the Satorra-Bentler (SB) scaled chi-square for robust ML estimation to handle the non-normality of data (Kline, 2011), the comparative fit index 
(CFI), the non-normed fit index (NNFI, also known as the Tucker-Lewis index-TLI), the standardized root mean square residual (SRMR), and the root mean square error of approximation (RMSEA) with Kline (2011) cutoff criteria (CFI > 0.950, NNFI > 0.950, SRMR < 0.080; RMSEA < 0.080). Besides, to check for any improper solutions of the model, individual parameter estimates and their estimated standard errors were examined (Lei $\& \mathrm{Wu}, 2007)$.

Figure 1. Research Framework

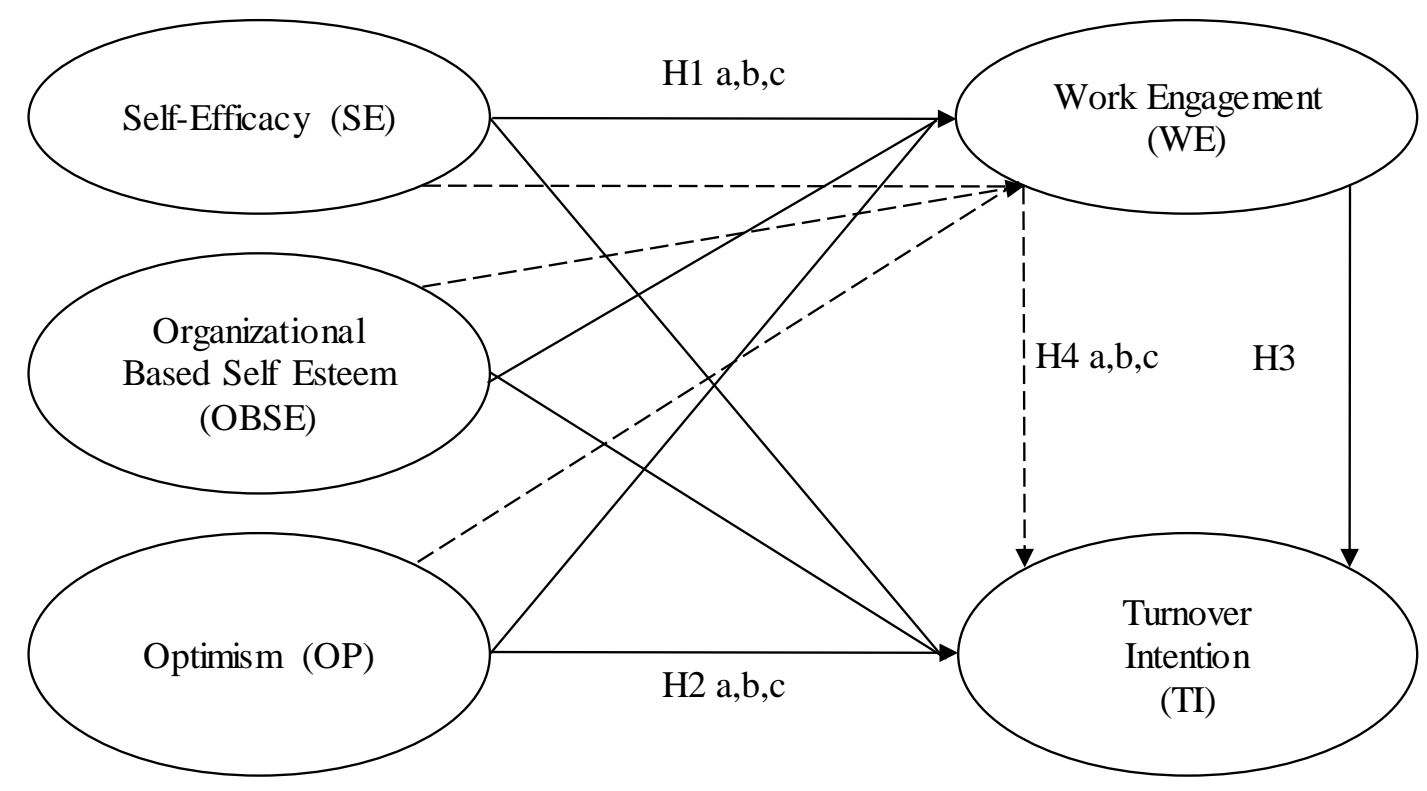

In this study, self-efficacy was measured using Schwarzer \& Jerusalem (1995) 10-item measurement ("I can always manage to solve difficult problems if I try hard enough", "If someone opposes me, I can find the means and ways to get what I want", "It is easy for me to stick to my aims and accomplish my goals", "I am confident that I could deal efficiently with unexpected events", "Thanks to my resourcefulness, I know how to handle unforeseen situations", "I can solve most problems if I invest the necessary effort", "I can remain calm when facing difficulties because I can rely on my coping abilities", "When I am confronted with a problem, I can usually find several solutions", "If I am in trouble, I can usually think of a solution", "I can usually handle whatever comes my way"). Organizational-based selfesteem was measured using 10 items developed by Pierce \& Gardner (2004) which is "I count around here", "I am taken seriously", "I am important", "I am trusted", "There is faith in me", "I can make a difference", "I am valuable", "I am helpful", "I am efficient", "I am cooperative". The Scheier et al. (1994) of optimism items used as measurement of optimism variable ("In uncertain times, I usually expect the best", "If something can go wrong for me, it will", "I am always optimistic about my future", "I hardly ever expect things to go my 
way", "I rarely count on good things happening to me", "Overall, I expect more good things to happen to me than bad").

Work engagement was assessed by using nine criteria of Schaufeli et al. (2002) with specific items as follows "I feel strong and vigorous to do my job", "When I do my job, I feel like I am bursting with energy", "When I do my job, I feel mentally strong", "I find my job challenging", "I am proud of my job", "I find my job to be full of meaning and purpose", "When I do my job, I forget everything else around me", "Time flies when I do my job", "I feel happy when I do my job intensively". While the turnover intention was measured using (Colarelli, 1982) guidance ("I frequently think of quitting", "I am planning to search a new job in the near future", "If I have my own way, I will be working for another organization"). Briefly, the proposed hypothesis model in this study can be seen in Figure 1.

\section{Result and Discussion}

As a preliminary analysis, reliability, and correlation matrix were examined, both internal consistencies using Cronbach's alpha and bivariate correlations among latent variables were calculated as shown in Table 1. The results indicate that all measures in this research had an acceptable level of reliability since the value of $\alpha$ ranged from 0.713 to 0.944 . Furthermore, since all bivariate correlations were less than 0.850 , the Pearson correlation indicated no multicollinearity issue (Lei \& Wu, 2007).

Table 1. Reliabilities and Correlations Among Latent Variables

\begin{tabular}{lcccccccc}
\hline \multirow{2}{*}{ Variable } & \multirow{2}{*}{ Mean } & Standard Deviation & $\boldsymbol{\alpha}$ & \multicolumn{5}{c}{ Bivariate Correlation } \\
\cline { 5 - 8 } & & & & $\mathbf{S E}$ & OBSE & OP & WE & TI \\
\hline SE & 3.010 & 0.394 & 0.896 & 1 & & & & \\
OBSE & 3.680 & 0.526 & 0.914 & 0.525 & 1 & & \\
OP & 3.810 & 0.574 & 0.787 & 0.489 & 0.450 & 1 & \\
WE & 5.010 & 0.980 & 0.944 & 0.472 & 0.488 & 0.482 & 1 & \\
TI & 2.170 & 0.793 & 0.713 & -0.156 & -0.306 & -0.333 & -0.366 & 1 \\
\hline
\end{tabular}

\section{Assessment of Model Fit}

Given that the measurement model and the full model were equivalent, to avoid the repetition, the model fit of the full model was assessed. The overall fit statistics of the proposed model are shown in Table 2. According to the results, the SB scaled chi-square of the model was statistically significant, $\chi^{2}(655)=1686.692, \mathrm{p}<.001$, indicating that the 
exact-fit hypothesis was rejected. Other fit statistics, however, were acceptable $(\mathrm{CFI}=0.978$ $[>0.950], \mathrm{NNFI}=0.976[>0.950] ; \mathrm{SRMR}=0.053[<0.080] ;$ and $\mathrm{RMSEA}=0.054[<$ 0.080]). Based on the results of the overall fit, we concluded that the model adequately fit the data.

Table 2. Overall Model Fit

\begin{tabular}{cccccc}
\hline & SB Scaled Chi-Square $(\boldsymbol{d} \boldsymbol{f})$ & CFI & NNFI & RMSEA & SRMR \\
\hline \multirow{2}{*}{ Proposed model } & $\chi^{2}(655)=1686.692, \mathrm{p}<.001$ & 0.978 & 0.976 & 0.053 & 0.051 \\
\hline
\end{tabular}

\section{Hypothesis Testing}

Table 3. Direct Effect Testing

\begin{tabular}{lcccc}
\hline Direct Effect & t-value & t-table & Criteria & Decision \\
\hline SE -> WE & 2.860 & 1.962 & t-value $>$ t-table & $\mathrm{H}_{1 \mathrm{a}}$ Accepted \\
OBSE -> WE & 4.280 & 1.962 & $\mathrm{t}$-value $>$ t-table & $\mathrm{H}_{1 \mathrm{~b}}$ Accepted \\
OP -> WE & 4.991 & 1.962 & $\mathrm{t}$-value $>$ t-table & $\mathrm{H}_{1 \mathrm{c}}$ Accepted \\
SE -> TI & 3.011 & -1.962 & t-value $>$ t-table & $\mathrm{H}_{2 \mathrm{a}}$ Rejected \\
OBSE -> TI & -2.230 & -1.962 & t-value $>$ t-table & $\mathrm{H}_{2 \mathrm{~b}}$ Accepted \\
OP -> TI & -3.810 & -1.962 & t-value $>$ t-table & $\mathrm{H}_{2 \mathrm{c}}$ Accepted \\
WE -> TI & -3.460 & -1.962 & t-value $>$ t-table & $\mathrm{H}_{3}$ Accepted \\
\hline
\end{tabular}

Based on the results from the assessment of the model fit, all proposed hypotheses were tested. The results of the proposed model indicated that the direct effect of SE on WE, OBSE on WE, and OP on WE were all statistically and positively significant. The t-value of proposed hypothesis 1 were higher than t-table $(2.860>1.962,4.280>1.962,4.991>1.962)$.

Thus, hypotheses 1a, 1b, and 1c were all accepted. This study support previous research by Choi \& Kang (2012), Luthans \& Peterson (2002), Mauno et al. (2007), Xanthopoulou et al. $(2007,2009)$ that concluded that personal resources were positive affects work engagement. The higher the level of self-efficacy, organizational-based self-esteem, and optimism, the more engaged employees on work or organization.

Table 3 also revealed that although the direct effect of OBSE on TI, OP on TI were all statistically and negatively significant, this study failed to prove the direct effect of SE on TI. While the t-value of proposed hypothesis $2 \mathrm{~b}, \mathrm{c}$ were higher than t-table $(-2.230>-1.962$, $3.810>-1.962$ ), the t-value of proposed hypothesis $2 \mathrm{a}$ were higher than t-table but in the 
opposite direction (3.011> -1.962). Therefore, hypotheses $2 \mathrm{~b}$ and $2 \mathrm{c}$ were accepted, but hypothesis 2a was rejected. Judeh \& Abou-Moghli (2019) argued that individual with a high level of self-efficacy usually perceived their job role differently and tend to take the initiative's action to demonstrate their skill set of competencies. As a result of these choices, high self-efficacy employees might believe that they are giving too much to their organization and hope that their hard work positively affects their outcome expectations (Chang et al., 2018). Therefore, they eventually negotiated more for higher salaries while at the same time seeing more alternative jobs/organizations offers in case they need to leave the organizations. It might be conceivable that if employees have high levels of self-efficacy, they are more likely to be engaged in their work. However, it does not indicate that these employees would have lower turnover intentions.

The results of the proposed model also showed that the direct impact of WE on TI was statistically and negatively significant. The t-value of proposed hypothesis 3 were higher than t-table $(-3.460>-1.962)$. Thus, hypothesis 3 was supported. This study support previous research by Halbesleben (2010), Agarwal et al., (2012), Bhatnagar, (2012), Kim (2017) that stated that there is a negative association between work engagement and turnover intention which means that the more engaged employees the less likely their intent to quit.

Table 4. Indirect Effect Testing

\begin{tabular}{|c|c|c|c|}
\hline \multirow{2}{*}{ Indirect Effect } & \multicolumn{2}{|c|}{ Confidence Interval } & \multirow{2}{*}{ Decision } \\
\hline & Lower & Upper & \\
\hline $\mathrm{SE}->\mathrm{WE}->\mathrm{TI}$ & -0.095 & -0.002 & $\mathrm{H}_{4 \mathrm{a}}$ Accepted \\
\hline OBSE -> WE -> TI & -0.105 & -0.019 & $\mathrm{H}_{4 \mathrm{~b}}$ Accepted \\
\hline $\mathrm{OP}->\mathrm{WE}->\mathrm{TI}$ & -0.137 & -0.028 & $\mathrm{H}_{4 c}$ Accepted \\
\hline
\end{tabular}

According to Preacher \& Hayes (2008), bootstrapping is the most powerful method for testing mediation effects under most sample conditions which assumes that the normal distribution assumption of variables is not fulfilled. Ryu et al. (2009) added that if the confidence interval level does not contain zero then the mediation effect is significant. The results presented in Table 4 show that work engagement played significant mediating roles in the relationship between SE and TI, OBSE and TI, OP and TI. The confidence interval value of all mediation models in this study does not contain zero, therefore $\mathrm{H}_{4 a}, \mathrm{H}_{4 b}, \mathrm{H}_{4 c}$ were accepted. Kim et al. (2013) and Shahpouri et al. (2016) stated that employees who have a higher level of self-efficacy, organizational-based self-esteem, and optimism may feel a 
stronger sense of work engagement that leads them to possess less turnover intention in their organization. These personal resources also could be shaped the motivational foundations that strengthen work engagement, in turn leading to accumulated resources in a positive work environment.

\section{Conclusion and Suggestion}

This study concluded that there is a positive relationship between personal resources (self-efficacy, organizational-based self-esteem, and optimism) and work engagement. The mediation role of work engagement in the relationship between self-efficacy, organizationalbased self-esteem, optimism, and turnover intention proves significantly in this study. Interestingly, this study found that there is a positive relationship of self-efficacy on turnover intention which means that the higher level of self-efficacy does not indicate the lower turnover intention. Employees with a high level of self-efficacy believe that they are giving too much to their organization Therefore, they eventually negotiated more for higher salaries while at the same time seeing more alternative jobs/organizations offers in case they are not appreciated enough for what they do for organizations. Further research should investigate another perspective of personal resources and its influences on work engagement and turnover intention. The degree of self-efficacy should also consider by researchers as one of the predictors of employee turnover intention.

\section{References}

Agarwal, U. A., Datta, S., Blake-Beard, S., \& Bhargava, S. (2012). Linking LMX, innovative work behaviour and turnover intentions. Career Development International, 17(3), 208230. https://doi.org/10.1108/13620431211241063

Bakker, A. B., \& Bal, M. P. (2010). Weekly work engagement and performance: A study among starting teachers. Journal of Occupational and Organizational Psychology, 83(1), 189-206. https://doi.org/10.1348/096317909X402596

Bakker, A. B., \& Demerouti, E. (2008). Towards a model of work engagement. Career Development International, 209-223. https://doi.org/10.1108/13620430810870476

Bakker, A. B., Demerouti, E., \& Sanz-Vergel, A. I. (2014). Burnout and work engagement: the JD-R approach. Annual Review of Organizational Psychology and Organizational Behavior, 1(1), 389-411. https://doi.org/10.1146/annurev-orgpsych-031413-091235 
Bhatnagar, J. (2012). Management of innovation: role of psychological empowerment, work engagement and turnover intention in the Indian context. The International Journal of Human Resource Management, 23(5), 928-951. https://doi.org/10.1080/09585192.2012.651313

Bowling, N. A., Eschleman, K. J., Wang, Q., Kirkendall, C., \& Alarcon, G. (2010). A metaanalysis of the predictors and consequences of organization-based self-esteem. Journal of Occupational and Organizational Psychology, 83(3), 601-626. https://doi.org/10.1348/096317909X454382

Carmeli, A., \& Weisberg, J. (2006). Exploring turnover intentions among three professional groups of employees. Human Resource Development International, 9(2), 191-206. https://doi.org/10.1080/13678860600616305

Chang, H.-Y., Friesner, D., Chu, T.-L., Huang, T.-L., Liao, Y.-N., \& Teng, C.-I. (2018). The impact of burnout on self-efficacy, outcome expectations, career interest and nurse turnover. Journal of Advanced Nursing, 74(11), 2555-2565. https://doi.org/10.1111/jan.13776

Choi, J. H., \& Kang, H. A. (2012). Job stress, personal resources, burnout, and work engagement in child counselors. Korean Journal of Childcare and Education, 8(5), 231252.

Colarelli, S. M. (1982). Methods of communication and job information, reactions to the job, and job survival: A field experiment (Doctoral dissertation). Retrieved from http://ezaccess.libraries.psu.edu/login?url=http://search.proquest.com.ezaccess.li\%0Abra ries.psu.edu/docview/303071954?accountid=13158

Demerouti, E., \& Cropanzano, R. (2010). From thought to action: Employee work engagement and job performance. In A. B. Bakker \& M. P. Leiter (Eds.), Work Engagement: A Handbook of Essential Theory and Research (pp. 147-163). New York: Psychology Press.

Egan, T. M., Yang, B., \& Bartlett, K. R. (2004). The effects of organizational learning culture and job satisfaction on motivation to transfer learning and turnover intention. Human Resource Development Quarterly, 15(3), 279-301. https://doi.org/10.1002/hrdq.1104

Hakanen, J. J., Bakker, A. B., \& Schaufeli, W. B. (2006). Burnout and work engagement among teachers. Journal of School Psychology, 43(6), 495-513. 
https://doi.org/10.1016/j.jsp.2005.11.001

Halbesleben, J. R. B. (2010). A meta-analysis of work engagement: Relationships with burnout, demands, resources, and consequences. In A. B. Bakker \& M. P. Leiter (Eds.), Work Engagement: A Handbook of Essential Theory and Research (pp. 102-117). New York: Psychology Press.

Halbesleben, J. R. B., \& Wheeler, A. R. (2008). The relative roles of engagement and embeddedness in predicting job performance and intention to leave. Work \& Stress, 22(3), 242-256. https://doi.org/10.1080/02678370802383962

Hobfoll, S. E. (1989). Conservation of resources: A new attempt at conceptualizing stress. American Psychologist, 44(3), 513-524. https://doi.org/10.1037/0003-066X.44.3.513

Hobfoll, S. E. (2002). Social and Psychological Resources and Adaptation. Review of General Psychology, 6(4), 307-324. https://doi.org/10.1037/1089-2680.6.4.307

Hobfoll, S. E., Johnson, R. J., Ennis, N., \& Jackson, A. P. (2003). Resource loss, resource gain, and emotional outcomes among inner city women. Journal of Personality and Social Psychology, 84(3), 632-643. https://doi.org/10.1037/0022-3514.84.3.632

Hughes, J. C., \& Rog, E. (2008). Talent management: A strategy for improving employee recruitment, retention and engagement within hospitality organizations. International Journal of Contemporary Hospitality Management, 20(7), 743-757. https://doi.org/10.1108/09596110810899086

Judeh, M., \& Abou-Moghli, A. A. (2019). Transformational leadership and employee intent to stay: mediating effect of employee self-efficacy. International Journal Of Academic Research in Business and Social Sciences, 9(12), 301-314. https://doi.org/10.6007/IJARBSS/v9-i12/6725

Kim, W. (2017). Examining mediation effects of work engagement among job resources, job performance, and turnover intention. Performance Improvement Quarterly, 29(4), 407425. https://doi.org/10.1002/piq.21235

Kim, W., Kolb, J. A., \& Kim, T. (2013). The relationship between work engagement and performance. Human Resource Development Review, 12(3), 248-276. https://doi.org/10.1177/1534484312461635

Kline, R. B. (2011). Principles and practice of structural equation modeling, 3rd ed. Principles and practice of structural equation modeling, 3rd ed. New York, NY, US: 
Guilford Press.

Lei, P.-W., \& Wu, Q. (2007). Introduction to Structural Equation Modeling: Issues and Practical Considerations. Educational Measurement: Issues and Practice, 26(3), 33-43. https://doi.org/10.1111/j.1745-3992.2007.00099.x

Lin, N., Jang, J., \& Roberts, K. R. (2018). Are employees with higher organization-based self-esteem less likely to quit? A moderated mediation model. International Journal of Hospitality Management, 73, 116-124. https://doi.org/10.1016/j.jhhm.2018.01.021

Luthans, F., \& Peterson, S. J. (2002). Employee engagement and manager self-efficacy. Journal of Management Development, 21(5), 376-387. https://doi.org/10.1108/02621710210426864

Luthans, F., Zhu, W., \& Avolio, B. J. (2006). The impact of efficacy on work attitudes across cultures. Journal of World Business, 41(2), 121-132. https://doi.org/10.1016/j.jwb.2005.09.003

Mauno, S., Kinnunen, U., \& Ruokolainen, M. (2007). Job demands and resources as antecedents of work engagement: A longitudinal study. Journal of Vocational Behavior, 70(1), 149-171. https://doi.org/10.1016/j.jvb.2006.09.002

Milam, L. A., Cohen, G. L., Mueller, C., \& Salles, A. (2019). The relationship between selfefficacy and well-being among surgical residents. Journal of Surgical Education, 76(2), 321-328. https://doi.org/10.1016/j.jsurg.2018.07.028

Mobley, W. H., Griffeth, R. W., Hand, H. H., \& Meglino, B. M. (1979). Review and conceptual analysis of the employee turnover process. Psychological Bulletin, 86(3), 493-522. https://doi.org/10.1037/0033-2909.86.3.493

Morrell, K., Loan-Clarke, J., \& Wilkinson, A. (2001). Unweaving leaving: The use of models in the management of employee turnover. International Journal of Management Reviews, 3(3), 219-244. https://doi.org/10.1111/1468-2370.00065

Picton, C., Kahu, E. R., \& Nelson, K. (2018). 'Hardworking, determined and happy': firstyear students' understanding and experience of success. Higher Education Research \& Development, 37(6), 1260-1273. https://doi.org/10.1080/07294360.2018.1478803

Pierce, J. L., \& Gardner, D. G. (2004). Self-esteem within the work and organizational context: a review of the organization-based self-esteem literature. Journal of Management, 30(5), 591-622. https://doi.org/10.1016/j.jm.2003.10.001 
Pradesa, H. A., Dawud, J., \& Affandi, M. N. (2019). Mediating role of affective commitment in the effect of ethical work climate on felt obligation among public officers. JEMA: Jurnal Ilmiah Bidang Akuntansi Dan Manajemen, 16(2), 133-146. https://doi.org/10.31106/jema.v16i2.2707

Preacher, K. J., \& Hayes, A. F. (2008). Asymptotic and resampling strategies for assessing and comparing indirect effects in multiple mediator models. Behavior Research Methods, 40(3), 879-891. https://doi.org/10.3758/BRM.40.3.879

Ryu, E., West, S. G., \& Sousa, K. H. (2009). Mediation and moderation: testing relationships between symptom status, functional health, and quality of life in HIV patients. Multivariate Behavioral Research, 44(2), 213-232. https://doi.org/10.1080/00273170902794222

Saks, A. M. (2006). Antecedents and consequences of employee engagement. Journal of Managerial Psychology, 21(7), 600-619. https://doi.org/10.1108/02683940610690169

Salanova, M., Schaufeli, W. B., Xanthopoulou, D., \& Bakker, A. B. (2010). The gain spiral of resources and work engagement: Sustaining a positive worklife. In A. B. Bakker \& M. P. Leiter (Eds.), Work Engagement: A Handbook of Essential Theory and Research (pp. 118-131). New York: Psychology Press. https://doi.org/10.4324/9780203853047

Schaufeli, W. B., \& Bakker, A. B. (2004). Job demands, job resources, and their relationship with burnout and engagement: a multi-sample study. Journal of Organizational Behavior, 25(3), 293-315. https://doi.org/10.1002/job.248

Schaufeli, W. B., \& Bakker, A. B. (2010). Defining and measuring work engagement: Bringing clarity to the concept. In A. B. Bakker \& M. P. Leiter (Eds.), Work Engagement: A Handbook of Essential Theory and Research (pp. 10-24). New York, NY, US: Psychology Press.

Schaufeli, W. B., Bakker, A. B., \& Van Rhenen, W. (2009). How changes in job demands and resources predict burnout, work engagement, and sickness absenteeism. Journal of Organizational Behavior, 30(7), 893-917. https://doi.org/10.1002/job.595

Schaufeli, W. B., Salanova, M., González-romá, V., \& Bakker, A. (2002). The measurement of engagement and burnout: A two sample confirmatory factor analytic approach. Journal of Happiness Studies, 3(1), 71-92. https://doi.org/10.1023/A:1015630930326

Scheier, M. F., Carver, C. S., \& Bridges, M. W. (1994). Distinguishing optimism from 
neuroticism (and trait anxiety, self-mastery, and self-esteem): A reevaluation of the Life Orientation Test. Journal of Personality and Social Psychology, 67(6), 1063-1078. https://doi.org/10.1037/0022-3514.67.6.1063

Scheier, M. F., Carver, C. S., \& Bridges, M. W. (2001). Optimism, pessimism, and psychological well-being. In E. C. Chang (Ed.), Optimism \& pessimism: Implications for theory, research, and practice. (pp. 189-216). Washington: American Psychological Association. https://doi.org/10.1037/10385-009

Schwarzer, R., \& Jerusalem, M. (1995). Generalized self-efficacy scale. In M. Johnston, S. C. Wright, \& J. Weinman (Eds.), Measures in Health Psychology: A User's Portfolio (pp. 35-37). Windsor, UK: NFER-Nelson.

Schyns, B., Torka, N., \& Gössling, T. (2007). Turnover intention and preparedness for change. Career Development International, 12(7), 660-679. https://doi.org/10.1108/13620430710834413

Shahpouri, S., Namdari, K., \& Abedi, A. (2016). Mediating role of work engagement in the relationship between job resources and personal resources with turnover intention among female nurses. Applied Nursing Research, 30, 216-221. https://doi.org/10.1016/j.apnr.2015.10.008

Shuck, B., Reio, T. G., \& Rocco, T. S. (2011). Employee engagement: An examination of antecedent and outcome variables. Human Resource Development International. https://doi.org/10.1080/13678868.2011.601587

Tuten, T. L., \& Neidermeyer, P. E. (2004). Performance, satisfaction and turnover in call centers. Journal of Business Research, 57(1), 26-34. https://doi.org/10.1016/S01482963(02)00281-3

Wefald, A. J., Reichard, R. J., \& Serrano, S. A. (2011). Fitting engagement into a nomological network: The relationship of engagement to leadership and personality. Journal of Leadership \& Organizational Studies, 18(4), 522-537. https://doi.org/10.1177/1548051811404890

Weigl, M., Hornung, S., Parker, S. K., Petru, R., Glaser, J., \& Angerer, P. (2010). Work engagement accumulation of task, social, personal resources: A three-wave structural equation model. Journal of Vocational Behavior. https://doi.org/10.1016/j.jvb.2010.03.002 
Personal resources and turnover intention among private-sector employees: Does work engagement still matter? by Ratna Tri Hardaningtyas

Winterton, J. (2004). A conceptual model of labour turnover and retention. Human Resource Development International, $\quad$ 7(3), 371-390. https://doi.org/10.1080/1367886042000201967

Wollard, K. K., \& Shuck, B. (2011). Antecedents to employee engagement. Advances in Developing Human Resources, 13(4), 429-446. https://doi.org/10.1177/1523422311431220

Xanthopoulou, D., Bakker, A. B., Demerouti, E., \& Schaufeli, W. B. (2007). The role of personal resources in the job demands-resources model. International Journal of Stress Management, 14(2), 121-141. https://doi.org/10.1037/1072-5245.14.2.121

Xanthopoulou, D., Bakker, A. B., Demerouti, E., \& Schaufeli, W. B. (2009). Work engagement and financial returns: A diary study on the role of job and personal resources. Journal of Occupational and Organizational Psychology, 82(1), 183-200. https://doi.org/10.1348/096317908X285633

Zhang, X., \& Bartol, K. M. (2010). Linking empowering leadership and employee creativity: the influence of psychological empowerment, intrinsic motivation, and creative process engagement. Academy of Management Journal, 53(1), 107-128. https://doi.org/10.5465/amj.2010.48037118 